\title{
STUDENTS' ASSESSMENT ON DIALOGUE AND ARGUMENTATION IN SOCIETY AND SCHOOL
}

\section{PROCJENA STUDENATA O DIJALOGU I ARGUMENTIRANJU U DRUŠTVU I ŠKOLI}

\author{
Marina Diković \\ Faculty of Educational Sciences, Juraj Dobrila University in Pula, Pula, Croatia \\ Fakultet za odgojne i obrazovne znanosti, Sveučilište Jurja Dobrile u Puli, Pula, Hrvatska
}

\section{Abstract}

The purpose of this study was to contribute to the model of preparing students for active argumentation in democratic societies and emphasize the teacher's role in classroom discussions $/ \mathbf{1} /$. As many as 245 university students reflected upon the statements in the Questionnaire about dialogue and argumentation. The research objective was to investigate the opinion of students - future teachers about argumentation. Results show that students evaluate in a more positive way the areas of argumentation at school from the aspect of the relationship among school stakeholders, with the relationship between pupils as the mostly evaluated; those who have the highest level of knowledge on the concept of argumentation evaluate more positively that engaging in different society activities develops cohesion, dialogue and argumentation. Students with better assessment on the important teachers' characteristics for argumentation show higher understanding for the encouragement of school activities which contribute to the development of dialogue.

\section{Introduction}

In order to help students, especially future teachers, learn how to adopt knowledge about argumentation and find out what the argumentation is, a process developing skills and abilities is required which will lead to practicing argumentation in the teaching process. It is very important to understand the environment of
Sažetak

Svrha ovoga rada bila je pridonijeti modelu pripreme učenika za aktivno argumentiranje u demokratskom društvu i naglasiti ulogu nastavnika u raspravama u učionici /1/. 245 studenata iznijelo je svoje mišljenje u Upitniku o dijalogu i argumentaciji. Cilj istraživanja bio je ispitati mišljenje studenata (budućih nastavnika) o argumentiranju. Rezultati pokazuju da studenti na pozitivniji način ocjenjuju područja argumentiranja u školi s aspekta odnosa između njezinih dionika, s tim da je najbolje ocijenjen odnos između učenika; oni koji imaju najviše znanja o konceptu argumentiranja pozitivno ocjenjuju to da uključivanje $\mathrm{u}$ različite aktivnosti $\mathrm{u}$ društvu razvija koheziju, dijalog i argumentiranje. Studenti s boljom procjenom važnih karakteristika nastavnika za argumentaciju pokazuju veće razumijevanje za poticanje školskih aktivnosti koje doprinose razvoju dijaloga.

scientific knowledge as a procedure of permanent conversation /2/. Argument is the constituent part of contradictory statements in a discussion. Besnard and Hunter /3/ emphasize that "input for a system based on monological argumentation is a knowledge base, together with a claim of interest, and the output is a constellation of arguments and counterarguments". The 
information which one should have in order for argumentation to actually occur are certain (or categorical) information, uncertain information, objective information (it is not necessarily correct or consistent), subjective information and hypothetical information. Some authors /4/ described argumentation elements: claim - the conclusion which we want to find by our argument; ground, data - facts and data which support the claim; warrant - reasons by which we connect the claim and ground; backing - additional reasons which help, explain the warrant; modal qualification - the level of plausibility we attribute to the claim; rebuttal - reasons by which we weaken, destroy the opponent claim. This Toulmin method of argumentation differs from other models in that it denotes facts as a justified stand and introduces consistency to objections in argumentation $/ \mathbf{5} /$.

An argument is a number of assumptions /3/. In an argument, which is first in the argumentation structure, the assumptions used are called the support (or, equivalently, the premises) of the argument, and its conclusion (singled out from many possible ones) is called the claim (or, equivalently, the consequent or the conclusion) of the argument. In argumentation contradiction, rebutting argument, undercutting argument and counterargument follow the first argument.

Argumentation can serve the function if the conclusion, developing from correlations with the support, is identic to the claim /5/. It is obvious that argumentation is in itself a skill, it requires a high level of managing and finding arguments as evidence in a certain situation which is, to a greater or smaller extent, difficult to predict. In argumentation it is important to find the largest possible number of correlations between the claim and conclusion. It is then said that argumentation is more successful and effective.

Interpretations clearly explain communication among persons. Argumentation denotes communication and ensures understanding in a dialogue and raises the level of the critical discourse quality. This is the procedure by which arguments and counterarguments are created and moved $/ 3 /$.

For argumentation it is necessary to be knowledgeable about the topic content-wise, which implies the knowledge of facts which are relevant for argumentation /1/. Values, such as accepting others' opinions, self-confidence, empathy, along with wide general knowledge/information, can lead to solutions in argumentation. It is advisable for co-speakers offering their argumentation to have a personal opinion on the topic in the context of emotional repulsion or emotional benevolence toward the topic claims. The argument should be developed and practiced in order to become and remain an important way of learning different subjects' content. Only in this way can we talk about competent children and young people who will influence change in school and the community. Therefore, university students as future teachers should learn about school relationships. To develop argumentation is schools, quality and positive relationships among all educational stakeholders, especially pupils, are necessary /6/ in discussions which are held in classrooms on a daily basis. However, research shows that teachers do not often lead discussions in the teaching process $/ \mathbf{1} /$ and when they do, they find it difficult to manage training. Engaging students in a classroom discussion means that teachers must change their daily teaching practices, including a modification in power relations $/ \mathbf{1} /$.

The relationship among teachers, pupils, parents and head-teachers can be observed in argumentation. Argumentation is structured in four parts $/ 5 /$. The first is the nature of things. In this case the claim can be a disputable judgement where things can be equalised, separated or quantitatively compared. The second is the subject of argumentation, the simple determination of the causal connection where causality as a thematic area is understood as the claim which encompasses the cause and consequence. In other words, the subject of the speaker's persuasiveness is the existence of a causal correlation. The third area of argumentation are value judgements about things, people, proceedings and abstractions (key concepts and norms) where subjectivity can be introduced, although it is important to defend the argument by reality, by rational means. Reaching the best decisions for the future is the fourth area of argumentation where the claim is a suggestion of action-taking which will 
solve a practical issue, and is most commonly defended causally (by the deduction of possible positive consequences) or through analogies (a similar solution has already shown to be successful).

Development of cohesion and dialogue in the community can be measured with activities' contribution. After conducting a research study, some authors /7/ came to the conclusion that young people raise the value of the positive efforts their schools and local experts make to progress communication and involvement, and are able to participate expressively in improving interrelation within their communities.

Certain school activities and courses contribute to the development of dialogue. Therefore, Snider and Schnurer /8/ emphasize the importance of dialogue in the curriculum. Children and young people thus practice negotiation skills that will help them develop social competences. Community activities considered to raise cohesion include sports, music and arts events, seasonal festivals (such as bonfire night and Christmas fairs), multicultural events (in the multicultural urban area), youth clubs $/ 7 /$. Contemporary pedagogy arguments relate to content, but also teaching methods. Since the purpose of active citizenship is to prepare children and young people to become informed citizens, it is the school's obligation to introduce children to argumentation as an important instrument of active citizenship in a democratic community /9/, /10/. Several educational courses, like, for instance, education for active citizenship, have recently been far preferable as a means for encouraging cohesion and dialogue in the community /11/. Furthermore, the value of argumentation can be recognised in decision making /12/.

Some authors /1/ describe two different kinds of teaching processes: 'teaching for discussion' which refers to the fact that students can respond to other students and teachers' different opinions and they must respect the opinions of others even though they do not agree with them, and 'teaching with discussions' which can help developing critical thinking and reasoning skills. It is difficult to expect from teachers to promote argumentation with their pupils if they do not have the necessary competencies for argumentation $/ \mathbf{1 3} /$, if they do not appreciate the importance of inciting discussions in schools. It is important to develop teachers' pedagogical competencies to practice both those types of teaching. Teachers' professional training should be developed in the context of their knowledge about argumentation, if they can be trained in this area, what are the argumentation aspects more accessible in classroom dialogues, how do argumentation tools help learning argumentation and how and who can help teachers to complement spoken argumentation with reading and writing.

Active listening during a dialogue in the community or school is necessary in communication. To use listening defines a clear expression of personal attitudes by arguments and active listening with the purpose of perceiving others' attitudes.

Since active citizenship is an excellent area where argumentation can be learnt and practiced aiming at children and young students as active citizens, the teaching methods (such as simulation - role playing, project work, discussion, etc.) and forms of work (such as group work, collaborative learning, etc.) used in the formation of citizens can also promote argumentation. By adopting such teaching methods learning outcomes are achieved. These methods primarily enable noticing of what is important in content, the analysis and use of information which will then be correlated to the already existing knowledge, as well as the critical judgement of its meaning. Teaching should be mostly about the application of those approaches which will develop pupils' activity. Using discussion in teaching process is the practice of classroom discussion as an instructional approach $/ \mathbf{1} /$.

The empirical study conducted by authors Newell et al. /14/ has shown that being in a collaborative environment contributes to the achievement of learning outcomes, skills and values. Pupils thus form their attitudes which will then be used in argumentation and by which they will solve problem tasks and will be able to conduct many research studies /15/. Learning activities, such as analysis, synthesis, problem-solving, experimentation, creativity, 
and examination of topics from multiple perspectives, usually encourage pupils to argument and reflection during the use of the already existing knowledge $/ \mathbf{1 6} /$. In these activities pupils form flexible and useful knowledge, work on projects and problem tasks, which can help them in their daily life.

Structured classroom discussions facilitate different pedagogical benefits, and are more effective at deepening students' understanding of course content and interest for the subject matter $/ \mathbf{1 7} /, / \mathbf{8} /$. By discussing in a more effective way pupils learn and acquire facts belonging to all subjects of teaching which they will be able to use, due to their interdisciplinarity, in active citizenship and in society.

Children and young people have to learn how to make arguments, they have to acquire the ways and strategies of argumentation. Argumentation belongs to rhetoric, but also to social disciplines such as pedagogy. In this paper argumentation will be observed in this context. Argumentation is an act of bringing forth evidence, or 'teaching for discussion' /1/, with the aim to come to the exchange of opinions and attitudes from different aspects, all with the purpose to protect human rights. A person must be able to prove the claim he/she supports because in such a way the social participation of individuals will be achieved, and it will lie on explanations of what they want to say, on their effort to explain and describe for their own benefit, but also for the benefit of the community they live and work in.

Important teacher's pedagogical competencies for adopting argumentation prepare university students - future teachers for their professional role. Social argumentation skills, such as, for instance, sharpness (the capability to abstract, differentiate and imply (apply), the recognition of the general in the singular), open-mindedness, eloquence (clarity of putting forward attitudes) and bringing forth words from a rich vocabulary can make argumentation better. All those activities, social skills and values can be an excellent inciter and promotor of the development of dialogue in schools $/ \mathbf{1 8} /, / 5 /$. In their empirical studies some authors describe that teachers integrate certain structures of educational strategies (e.g. group discussions and presentations) directed by teaching $/ \mathbf{1 9} /, / 20 /, / 21 /$. To implement those strategies, in order to develop argumentation, teachers must be competent /6/ and able to practice instructional applies associated with argumentation in the science teaching /21/. This work could represent a contribution to the lack of existence of research in the field of student - future teacher surveys about argumentation. The theoretical source of this paper emphasizes the importance of relating argumentation within the local community with particular emphasis on school. Therefore, it is important to investigate the extent to which students as future teachers are sensitive to this problem and how different their opinions are in some aspects. Critical reasoning could be an important way of learning and teaching the concept of argumentation.

\section{The purpose of the study}

The purpose of this study was to contribute to dialogue and argumentation at the community and school level. The basis of this study was the model of preparing students for active argumentation in democratic societies and emphasize the teacher's role in classroom discussions $\mathbf{1} \mathbf{1}$. The teacher's role in motivation for dialogue and discussions is noticed in the encouragement of dialogues about controversial topics. It is, moreover, important to prepare for the realisation of class discussions. Schuitema and other authors /1/ describe the structural characteristics of discussions which they analyse in their work: pupils participation (to which extent pupils participate in discussions and how much they introduce new contents to it), the reaction of pupils to one another (to what extent pupils communicate among themselves), transformation (the measure to which participants participate in their common thinking and build up common ideas) and the meaning of the discussion content (what is the quality of arguments in class discussions). Their research has led them to the conclusion that the results support our statement that the level to which teachers regulate the discussion is related to the organization and content features of the discussion, also in cases when teachers direct the discussion content, pupils have lower possibilities to put forward their own arguments. Nevertheless, 
the authors think that the extent to which teachers control the discussion may be vital for the quality of the discussion content $/ \mathbf{1} /$. They indicate the existence of a difference between 'teaching with' and 'teaching for' discussion and explain that 'teaching for' discussion is more efficient when we talk about pupil-oriented teaching.

\section{Research questions}

The research objective of the conducted research was to examine the opinion of students future teachers about dialogue and argumentation in the community with special emphasis given to schools.

Based on the research objective, three research questions were created:

1. Is there connectedness between students' knowledge about argumentation and their assessments of school relationships?

2. Is there connectedness between students' knowledge about argumentation and their assessment of the contribution to the development of dialogue in the community?

3. Is there connectedness between students' assessments of teachers' characteristics important for argumentation and the school activities which contribute to the development of dialogue?

\section{Method}

\section{Sample}

As many as 245 university students from Croatia participated in the research. Of the total number, 69 of them were male students (28.2\%) and 176 were female students $(71.8 \%)$. The examinees' average age was $23(22.73 \%)$. The majority of students attended courses in humanities $(\mathrm{N}=162 ; 66.10 \%)$ and in educational sciences $(\mathrm{N}=46 ; 18.8 \%)$. The lowest number of students who participated in the research were studying technical sciences $(\mathrm{N}=23 ; 9.3 \%)$ and applied arts $(\mathrm{N}=14 ; 5.7 \%)$.

The majority of students were in their fourth year of study $(\mathrm{N}=134 ; 54.7 \%)$, then in the first $(\mathrm{N}=47 ; 19.2 \%)$, the third $(\mathrm{N}=34 ; 13.9 \%)$ and the second $(\mathrm{N}=26 ; 10.6 \%)$, while there were only four students of the fifth year of study (1.6 $\%)$.
As future teachers of various subjects that will have the possibility to implement argumentation dialogue in their teaching, the students were selected to be participants in the study.

\section{Instrument and procedure}

For the need of this paper's study the Questionnaire about dialogue and argumentation was constructed. Knowledge about argumentation was measured with the use of statements on argumentation with regard to the concept of argumentation /3/, /5/ as well as the value of argumentation in the teaching process $/ \mathbf{1} /$. Statements such as: Argumentation is ...the initial process in the first days of education in a school institution., ...the process which consists of a thesis, assumption and explanation, or ...the process which can be disproved by disputing the logic of the explanation-thesis correlation were offered.

The assessment of school relationships encompassed the evaluation scale of the extent to which areas of argumentation can be developed in schools /5/. It related to the relationship among education stakeholders (pupil - pupil, pupil - teacher, teacher - teacher, teacher - parent, teacher - head-teacher) and four areas of argumentation were offered (the nature of a certain thing; determination of the causal connection; the value system about things, people, proceedings and abstractions (concepts and norms); reaching the best decisions for the future).

The contribution to activities in the community included the extent to which respondents personally make use of dialogues as a means to solve problems, and students could answer that question on a five-degree scale (a - "not at all" up to e - "very much"). It also included their opinion, based on their experience as primary and secondary school students, about the extent to which the development of the culture of dialogue is developed in schools. Furthermore, activities in the community were measured by a five-degree Likert type scale (1 - "extremely low" up to 5 - "a lot"). The offered activities were those which develop cohesion, dialogue and argumentation in a community, for instance: humanitarian help, psycho-social activities, ecological activities etc. Secondly, the characteristics of teachers which are important for argu- 
mentation were also questioned. Many characteristics /18/, /5/ such as knowledgeability about the discussion topic, accepting others' opinions, emotional benevolence toward the topic claims, eloquence (clearness of attitudes brought forth), active listening, etc. were offered.

Assessment of the level to which certain school activities contribute to the development of dialogue and activities such as motivation (interest)

\begin{tabular}{|c|c|c|}
\hline Variable & $\begin{array}{l}\text { Number of state- } \\
\text { ments }\end{array}$ & Theoretical source \\
\hline Knowledge about argumentation & 12 & $\begin{array}{l}\text { Besnard, \& Hunter, 2008; } \\
\text { Škarić, 2011; Schuitema et al., } \\
2018\end{array}$ \\
\hline Assessment of school relationships & 20 & $\begin{array}{l}\text { Škarić, 2011, based on } \\
\text { Fahnesttock, \& Secor, } 1990\end{array}$ \\
\hline $\begin{array}{l}\text { Evaluation of the activities' contribution to the develop- } \\
\text { ment of cohesion and dialogue in the community }\end{array}$ & 6 & Besnard, \& Hunter, 2008 \\
\hline $\begin{array}{l}\text { Assessment of the level to which certain school activities } \\
\text { contribute to the development of dialogue }\end{array}$ & 19 & $\begin{array}{l}\text { Besnard, \& Hunter, 2008; } \\
\text { Schuitema et al., } 2018\end{array}$ \\
\hline $\begin{array}{l}\text { Evaluation of teachers' characteristics important for argu- } \\
\text { mentation }\end{array}$ & 19 & Erduran, 2007; Škarić, 2011 \\
\hline
\end{tabular}

Table 1. Description of the questionnaire

The reliability of the questionnaire was measured with Cronbach's Alpha and it was as high as 0.95 . The questionnaire was administered in groups during regular lectures. It was filled in anonymously with the students' oral consent. Descriptive and inferential statistical procedures were used for data analyses in SPSS (version 24.0).

\section{Results and discussion}

Students' knowledge about argumentation and assessment of school relationships

Results lead to the conclusion that the students' knowledge about argumentation is "mediocre" or "high". The average values of correlation with statements about argumentation equalled to $\mathrm{M}=2.56(\mathrm{SD}=1.12)$ for the statement "a process containing an explanation" up to $\mathrm{M}=4.07$ $(S D=0.91)$ for the statement "a process consisting of a thesis, assumption and explanation". The latter is also the most complete statement when it comes to argumentation as a technical for argumentation, putting forward valid qualitative (theoretical) evidence according to different variables important for argumentation, emotional repulsion toward topic claims, self-confidence, wide general knowledge/information and others were offered. All variables are described in Table 1. process which implies a number of other activities used by two or more persons to argument in a community.

Regarding school relationships and the argumentation area, the area "determining the causal connection" for the relation "teacher teacher" ( $\mathrm{M}=4.09$; $\mathrm{SD}=0.76)$ was highly estimated. The area "value judgements about things, people, proceedings and abstractions (concepts and norms)" $(\mathrm{M}=4.01 ; \mathrm{SD}=0.79)$ and "reaching the best decisions for the future" (M $=4.00 ; \mathrm{SD}=0.86$ ) for the same relation were also highly evaluated. Since the area the "nature of a certain thing (in case when things in claims are equalised, separated or quantitatively compared, i.e. when the meaning of concepts is considered)" for the relation "pupil - pupil" equalled to $\mathrm{M}=3.58$ ( $\mathrm{SD}=0.82$ ), it can be concluded that all areas and all relations were highly evaluated.

The correlation between variables is shown in the correlation matrix (Table 2.). 
The research question if there is connectedness between students' knowledge about argumentation and their assessments of school relationships was examined. Based on the results, students estimate in a more positive way the areas of argumentation at school from the aspect of relationship among school stakeholders, with the relationship between pupils as the mostly evaluated.

The Pearson coefficient (r) (Table 2.) confirms that the overall students' answers have a cognitive aspect, which means that their knowledge about argumentation is related to their answers about school relationships $(\mathrm{r}=0.53 ; \mathrm{p}<0.01)$. Putting forward personal attitudes is more and more promoted and valued in the contemporary school, and teachers allow their students to

\begin{tabular}{|c|c|c|c|c|c|c|c|c|c|c|}
\hline variables & $\begin{array}{l}\text { involve- } \\
\text { ment in } \\
\text { commu- } \\
\text { nity ac- } \\
\text { tivities }\end{array}$ & $\begin{array}{l}\text { knowledg } \\
\text { e of argu- } \\
\text { menta- } \\
\text { tion }\end{array}$ & $\begin{array}{l}\text { teachers' } \\
\text { characte- } \\
\text { ristics }\end{array}$ & $\begin{array}{l}\text { relations } \\
\text { in } \\
\text { school }\end{array}$ & $\begin{array}{l}\text { rela- } \\
\text { tion } \\
\text { pu- } \\
\text { pil- } \\
\text { pupil }\end{array}$ & $\begin{array}{l}\text { rela- } \\
\text { tion } \\
\text { pu- } \\
\text { pil- } \\
\text { te- } \\
\text { ache } \\
\text { r }\end{array}$ & $\begin{array}{l}\text { rela- } \\
\text { tion } \\
\text { te- } \\
\text { ache } \\
\text { r-te- } \\
\text { ache } \\
\text { r }\end{array}$ & $\begin{array}{l}\text { rela- } \\
\text { tion } \\
\text { te- } \\
\text { ache } \\
\text { r-pa- } \\
\text { rent }\end{array}$ & $\begin{array}{l}\text { rela- } \\
\text { tion te- } \\
\text { acher- } \\
\text { head- } \\
\text { master }\end{array}$ & $\begin{array}{l}\text { encou- } \\
\text { raging } \\
\text { school } \\
\text { activi- } \\
\text { ties }\end{array}$ \\
\hline $\begin{array}{l}\text { involve- } \\
\text { ment in } \\
\text { commu- } \\
\text { nity acti- } \\
\text { vities }\end{array}$ & & $0,38^{* *}$ & $0,23^{* *}$ & $0,27^{* *}$ & $\begin{array}{l}0,30^{*} \\
*\end{array}$ & $\begin{array}{l}0,20^{*} \\
*\end{array}$ & $\begin{array}{l}0,24^{*} \\
*\end{array}$ & $\begin{array}{l}0,19^{*} \\
*\end{array}$ & $0,20^{* *}$ & $0,14^{*}$ \\
\hline $\begin{array}{l}\text { knowledg } \\
\text { e of argu- } \\
\text { menta- } \\
\text { tion }\end{array}$ & $0,38^{* *}$ & & $0,44^{* *}$ & $0,53^{* *}$ & $\begin{array}{l}0,51^{*} \\
*\end{array}$ & $\begin{array}{l}0,47^{*} \\
*\end{array}$ & $\begin{array}{l}0,43^{*} \\
*\end{array}$ & $\begin{array}{l}0,39^{*} \\
*\end{array}$ & $0,39^{* *}$ & $0,39^{* *}$ \\
\hline $\begin{array}{l}\text { teachers' } \\
\text { characte- } \\
\text { ristics }\end{array}$ & $0,23^{* *}$ & $0,44^{* *}$ & & $0,49^{* *}$ & $\begin{array}{l}0,50^{*} \\
*\end{array}$ & $\begin{array}{l}0,40^{*} \\
*\end{array}$ & $\begin{array}{l}0,43^{*} \\
*\end{array}$ & $\begin{array}{l}0,35^{*} \\
*\end{array}$ & $0,35^{* *}$ & $0,70^{* *}$ \\
\hline $\begin{array}{l}\text { relations } \\
\text { in school }\end{array}$ & $0,27^{* *}$ & $0,53^{* *}$ & $0,49^{* *}$ & & $\begin{array}{l}0,78^{*} \\
*\end{array}$ & $\begin{array}{l}0,82^{*} \\
*\end{array}$ & $\begin{array}{l}0,83^{*} \\
*\end{array}$ & $\begin{array}{l}0,84^{*} \\
*\end{array}$ & $0,85^{* *}$ & $0.52^{* *}$ \\
\hline $\begin{array}{l}\text { relation } \\
\text { pupil-pu- } \\
\text { pil }\end{array}$ & $0,30^{* *}$ & $0,51^{* *}$ & $0,50^{* *}$ & $0,78^{* *}$ & & $\begin{array}{l}0,62^{*} \\
*\end{array}$ & $\begin{array}{l}0,55^{*} \\
*\end{array}$ & $\begin{array}{l}0,53^{*} \\
*\end{array}$ & $0,53^{* *}$ & $0,47^{* *}$ \\
\hline $\begin{array}{l}\text { relation } \\
\text { pupil-te- } \\
\text { acher }\end{array}$ & $0,20^{* *}$ & $0,47^{* *}$ & $0,40^{* *}$ & $0,82^{* *}$ & $\begin{array}{l}0,62^{*} \\
*\end{array}$ & & $\begin{array}{l}0,61^{*} \\
*\end{array}$ & $\begin{array}{l}0,59^{*} \\
*\end{array}$ & $0,59^{* *}$ & $0,43^{* *}$ \\
\hline $\begin{array}{l}\text { relation } \\
\text { teacher- } \\
\text { teacher }\end{array}$ & $0,24^{* *}$ & $0,43^{* *}$ & $0,43^{* *}$ & $0,83^{* *}$ & $\begin{array}{l}0,55^{*} \\
*\end{array}$ & $\begin{array}{l}0,61^{*} \\
*\end{array}$ & & $\begin{array}{l}0,62^{*} \\
*\end{array}$ & $0,67^{* *}$ & $0,46^{* *}$ \\
\hline $\begin{array}{l}\text { relation } \\
\text { teacher- } \\
\text { parent }\end{array}$ & $0,19^{* *}$ & $0,39^{* *}$ & $0,35^{* *}$ & $0,84^{* *}$ & $\begin{array}{l}0,53^{*} \\
*\end{array}$ & $\begin{array}{l}0,59^{*} \\
*\end{array}$ & $\begin{array}{l}0,62^{*} \\
*\end{array}$ & & $0,69^{* *}$ & $0,38^{* *}$ \\
\hline $\begin{array}{l}\text { relation } \\
\text { teacher- } \\
\text { headmas- } \\
\text { ter }\end{array}$ & $0,20^{* *}$ & $0,39^{* *}$ & $0,35^{* *}$ & $0,85^{* *}$ & $\begin{array}{l}0,53^{*} \\
*\end{array}$ & $\begin{array}{l}0,59^{*} \\
*\end{array}$ & $\begin{array}{l}0,67^{*} \\
*\end{array}$ & $\begin{array}{l}0,69^{*} \\
*\end{array}$ & & $0,40^{* *}$ \\
\hline
\end{tabular}
surrounding them. Such a learning method influences the students' overall knowledge. This is also confirmed by authors Klem and Connell /22/ /13/ and according to them personalized learning environments contribute to student success. The objective of contemporary schools must be to educate students about how to take part in discussions in the everyday learning and teaching of a democratic society /1/. Moreover, the study conducted by some authors /23/ shows that students who learn in an environment promoting good school relationships achieve better results in their knowledge.

(SSN $1330-0067$ 


\begin{tabular}{|c|c|c|c|c|c|c|c|c|c|}
\hline $\begin{array}{l}\text { encoura- } \\
\text { ging } \\
\text { school ac- } \\
\text { tivities }\end{array}$ & $0,14^{*}$ & $0,39^{* *}$ & $0,70^{* *}$ & $0,52^{* *}$ & $\begin{array}{l}0,47^{*} \\
*\end{array}$ & $\begin{array}{l}0,43^{*} \\
*\end{array}$ & $\begin{array}{l}0,46^{*} \\
*\end{array}$ & $\begin{array}{l}0,38^{*} \\
*\end{array}$ & $0,40^{* *}$ \\
\hline
\end{tabular}

Table 2. The correlation matrix of students' answers $(\mathrm{N}=245)$

The highest correlation in the knowledge about argumentation and relationships was obtained between knowledge answers and the relation "pupil - pupil" ( $\mathrm{r}=0.53 ; \mathrm{p}<0.01)$. This means that, according to students' answers, the better pupils' knowledge about argumentation is, the better their relationship with other co-pupils. During their education pupils have high success and education aims ahead of them and this greatly influences the relationships among them. The success of collaborative learning depends on the quality of student communication /6/. Less disturbing teacher regulation of content may allow more room for student contributions and may lead to a more authentic discussion resulting in supplementary contributions from students and in more students answering to each other $/ \mathbf{1} /$.

The correlation of answers about argumentation knowledge and the relation "pupil teacher" is somewhat less strong $(\mathrm{r}=0.47$; $\mathrm{p}<$ 0.01). Regarding the relationship between teachers and students' knowledge about argumentation, it can be said that it also exists ( $r=$ $0.43 ; p<0.01$ ). The lowest correlation is between students' knowledge about argumentation and the relation "teacher - parent" and "teacher head-teacher" ( $r=0.39$; $\mathrm{p}<0.01)$. School relationships are important for the pupils' acquisition of knowledge, but regarding the fact that the learning and teaching triangle is made not only by content, but also by teachers, it is logical that on the ladder of importance in relationships they take the first place. Parents and headteachers can help pupils learn and acquire knowledge in various ways, and this will be manifested in a successful school culture.

\footnotetext{
Students' knowledge about argumentation and the community activities' contributions to the development of cohesion and dialogue

It can be noticed that students gave the smallest evaluation to the fact that the inclusion of "ecological activities" $(\mathrm{M}=3.48 ; \mathrm{SD}=1.07)$ develops

cohesion, dialogue and argumentation in a community, while according to the same students those are "activities of animal protection" $(\mathrm{M}=4.00 ; \mathrm{SD}=1.33)$ to the greatest extent. Other offered activities were "moderately" to "highly" evaluated and it can be concluded that activities such as "humanitarian help, educational activities" and "health activities" can also develop argumentation in the school community.

Students' assessments also talk about the choice of activities which contribute to the development of dialogue in schools. The activity which, according to students, mostly encourages dialogue is "active listening" $(\mathrm{M}=4.55$; $\mathrm{SD}=0.66)$, while the one that does it the least is "emotional repulsion towards topic claims" $(\mathrm{M}=3.19$; $\mathrm{SD}=$ 1.10). The activities which, also according to students, encourage the development of dialogues in schools to a larger extent are: "knowledgeability about the discussion topic" ( $\mathrm{M}=$ 4.51 ; $\mathrm{SD}=0.64)$, "open-mindedness" $(\mathrm{M}=4.40$; $\mathrm{SD}=0.71)$ and "motivation (interest) for argumentation" ( $\mathrm{M}=4.40$; $\mathrm{SD}=0.78)$.

Results show that students who have the highest level of knowledge on the concept of argumentation evaluate more positively that engaging in different society activities develops cohesion, dialogue and argumentation. Results confirm the research question when there is connectedness between students' knowledge about argumentation and their assessment of the contribution to the development of dialogue in the community.

The Pearson coefficient (r) (Table 2.) was calculated based on the obtained results. Correlation was confirmed. This means that students' knowledge about argumentation is moderately correlated with answers about inclusion in activities which develop cohesion, dialogue and argumentation $(\mathrm{r}=0.38 ; \mathrm{p}<0.01)$. It is proved that it is possible to include pupils in the productive argumentation discourse if they have acquired the knowledge about asking questions /24/ and thus prepare them to individually develop dialogue and discussions with peers /15/, 
$/ 25 /, / \mathbf{1} /$. In this context they will be able to negotiate about situations of the utmost importance for the community $/ \mathbf{2 6} /$ because if person has no information, he/she has no arguments /3/. Using argumentation strategies /27/ can help future teachers promote argumentation.

The evaluation of teachers' characteristics important for argumentation and encouragement of school activities which contribute to the development of dialogue

The teachers' characteristics which are important for argumentation, as students' answers show, indicate their high level of presence in the argumentation process. Students have given the highest evaluation to "knowledgeability about the discussion topic" ( $\mathrm{M}=$ 4.64; $\mathrm{SD}=0.67$ ), while the lowest evaluated is "emotional repulsion toward topic claims" ( $\mathrm{M}=$ 2.98 ; SD = 1.14). According to students' opinions, the characteristics which are especially important for the argumentation process are: "active listening" ( $\mathrm{M}=4.52 ; \mathrm{SD}=0.69)$, "motivation (interest) for argumentation" ( $\mathrm{M}=4.47$; $\mathrm{SD}=$ 0.74 ) and "eloquence (clearness of putting forward attitudes)" ( $\mathrm{M}=4.43 ; \mathrm{SD}=0.71)$. Teachers are important for the promotion of various pupils' skills, especially for the correct linguistic literacy /14/. This is an exceptionally important activity for the shaping of attitudes in argumentation.

The third research question, if there is connectedness between students' assessments of teachers' characteristics important for argumentation and the school activities which contribute to the development of dialogue, was explored. Students with better assessment on the important teachers' characteristics for argumentation appreciate more positively the encouragement of school activities which contribute to the development of dialogue. Results (Table 2.) show that there is a high correlation between students' answers about teachers' characteristics important for argumentation and answers about the encouragement of school activities contributing to the development of dialogue ( $\mathrm{r}$ $=0.70, p<0.01)$. Some authors $/ 14 /$ have proved how much learning and teaching are important for argued reading and writing. They add that this is the only way to develop the dialogue in schools promoted by teachers. Teachers' competencies are important for the promotion of shaping attitudes important for argumentation /28/. An obstacle can be formed if teachers do not feel prepared to engage their students in discussions, especially about controversial issues $/ \mathbf{1} /$. Competent teachers will know how to ensure the environment and which activities to prepare to make pupils learn by argumentation $/ 13 /$, and they will also participate by asking pupils adequate questions. The way teachers monitor the classroom discussion influences the extent to which the discussion will be open-ended and open for students to contribute as equivalents, educating issues and questions and discovering multiple viewpoints $/ \mathbf{1} /$. The teachers' role should be direct, leading, but not too direct so that pupils could be as present as possible in classroom discussions.

\section{Conclusion}

Sources on argumentation indicate the importance of acquiring argumentation knowledge, especially for future teachers /27/ who should be a role model to pupils in developing dialogue and argumentation in school and in the local community. This emphasizes the importance of exploring argumentation in the local community with particular emphasis on school.

This study results indicate the need of constant dialogues and argumentation in the classroom environment relationships $/ \mathbf{1} /$, as to make pupils active citizens who influence the social community surrounding them by expressing their personal attitudes. Furthermore, knowledge about argumentation strongly influences the inclusion of activities in the social community by which social skills (for instance, cohesion, dialogue and argumentation) are encouraged and developed. In this context, it is important to point to the role of the teacher as the one who will use his/her pedagogic competencies to guide pupils toward the protection of their rights and the promotion of freedom and responsibility.

The conclusions of the research presented in this paper could help the elucidation on the importance of argumentation in order to identify 
university students - future teachers' recognition of the necessity of implementing argumentation as an important educational tool. University students in this research have a more positive assessment on the parts of argumentation at school from the aspect of relationship among school stakeholders, with the relationship between pupils as the mostly evaluated. Moreover, students who have the highest level of knowledge on the concept of argumentation evaluate more positively that engaging in different society activities develops cohesion, dialogue and argumentation. Results also show that students with better assessment on the important teachers' characteristics for argumentation appreciate more the encouragement of school activities which contribute to the improvement of dialogue.

Teaching will be pupil-centred. By argumentation they will bring forth their attitudes in school community dialogues and discussions in the narrower and wider community. They will thus become active citizens who know how to develop negotiation skills. Students' argumentation relates to their scientific knowledge /20/, and future teachers must practice argumentation at universities, and learn how to teach making questions in educational situations $/ \mathbf{1 5} /, / 25 /$. This research has some limitations. The first one is that the students' opinion is based on their memory of the time they attended primary and secondary school. Further, it could be expanded into other university studies where future teachers are educated.

The intention of this research was to extend the concept of university students - future teachers' argumentation to develop the quality of structural elements in the educational area.

A recommendation in this research can be for future research to include actual primary or secondary schools' teachers in the sample. This can be an opportunity to investigate and correlate certain opinions held by important figures of the educational system, the educational stakeholders.

\section{Notes}

/1/ Schuitema, J., Radstake, H., van de Pol, J., \& Veugelers, W. (2018), »Guiding classroom discussions for democratic citizenship education «, Educational Studies, 44(4), pp. 377-407. DOI: 10.1080/03055698.2017.1373629

/2/ Veerman, A., Andriessen, J., \& Kanselaar, G. (2002), „Collaborative argumentation in academic education «, Instructional Science, 30(3), pp. 155-186.

13/ Besnard, P., \& Hunter, A. (2008), Elements of argumentation (Vol. 47), Cambridge: MIT press.

14/ Toulmin, S. E. (2003), The Uses of Argument. Updated Edition, Cambridge: Cambridge University Press.

/5/ Škarić, I. (2011), Argumentacija, Zagreb: Nakladni zavod Globus.

/6/ Kaendler, C., Wiedmann, M., Rummel, N., \& Spada, H. (2015), »Teacher competencies for the implementation of collaborative learning in the classroom: A framework and research review «, Educational Psychology Review, 27(3), pp. 505-536.

/7/ Shuayb, M., Sharp, C., Judkins, M., \& Hetherington, M. (2009), Young People's Perceptions of Effective Community Cohesion Practices, Berkshire: National Foundation for Educational Research.

/8/ Snider, A. C., \& Schnurer, M. (2002), Many sides: Debate across the curriculum, New York, NY: The International Debate Education Association.

/9/ Joshi, P. (2016), »Argumentation in democratic education: The crucial role of values", Theory into practice, 55(4), pp. 279-286.

/10/ Segal, A., Pollak, I., \& Lefstein, A. (2017), »Democracy, voice and dialogic pedagogy: The struggle to be heard and heeded «, Language and education, 31(1), pp. 6-25.

/11/ Shuayb, M. (Ed.). (2012), Rethinking education for social cohesion: International case studies, Basingstoke: Palgrave Macmillan.

/12/ Jiménez-Aleixandre, M. P., \& Erduran, S. (2007), »Argumentation in science education: An overview«, In: Argumentation in science education. Springer, Dordrecht (pp. 3-27).

/13/ Jiménez-Aleixandre, M. P. (2007), »Designing argumentation learning environments«, In Argumentation in science education. Springer, Dordrecht (pp. 91-115).

14/ Newell, G. E., Beach, R., Smith, J., \& VanDerHeide, J. (2011), »Teaching and learning argumentative reading and writing: A review of research«, Reading Research Quarterly, 46(3), pp. 273-304.

/15/ Chinn, C. A., \& Clark, D. B. (2013), »Learning through collaborative argumentation «. In: C. E. Hmelo-Silver, C. A. Chinn C. K. K. Chan, \& A. M. O'Donnell (Eds.) International Handbook of Collaborative Learning, New York: Taylor \& Francis (pp. 314-332). 
/16/ Grabinger, R. S., \& Dunlap, J. C. (1995), »Rich environments for active learning: A definition «, ALT-J, 3(2), pp. 5-34.

/17/ Merrell, B., Calderwood, K. J., \& Graham, T. (2017), »Debate across the disciplines: Structured classroom debates in interdisciplinary curricula«, Contemporary Argumentation \& Debate, 37, pp. 5774.

/18/ Erduran, S. (2007), »Methodological foundations in the study of argumentation in science classrooms«, In: Argumentation in science education. Springer, Dordrecht (pp. 47-69).

/19/ Erduran, S., Ardac, D., \& Yakmaci-Guzel, B. (2006), »Learning to teach argumentation: Case studies of pre-service secondary science teachers«, Eurasia Journal of Mathematics, Science and Technology Education, 2(2), pp. 1-14.

/20/ Von Aufschnaiter, C., Erduran, S., Osborne, J., \& Simon, S. (2008), »Arguing to learn and learning to argue: Case studies of how students' argumentation relates to their scientific knowledge «, Journal of Research in Science Teaching: The Official Journal of the National Association for Research in Science Teaching, 45(1), pp. 101-131.

/21/ Osborne, J., Simon, S., Christodoulou, A., Howell-Richardson, C., \& Richardson, K. (2013), »Learning to argue: A study of four schools and their attempt to develop the use of argumentation as a common instructional practice and its impact on students«, Journal of Research in Science Teaching, 50(3), pp. 315-347.
/22/ Klem, A. M., \& Connell, J. P. (2004), »Relationships matter: Linking teacher support to student engagement and achievement «, Journal of school health, 74(7), pp. 262-273.

/23/ MacNeil, A. J., Prater, D. L., \& Busch, S. (2009), »The effects of school culture and climate on student achievement «, International Journal of Leadership in Education, 12(1), pp. 73-84.

/24/ Chin, C., \& Osborne, J. (2010), »Students' questions and discursive interaction: Their impact on argumentation during collaborative group discussions in science «, Journal of research in Science Teaching, 47(7), pp. 883-908.

/25/ Cross, T. L., \& Coleman, L. J. (2014), »Schoolbased conception of giftedness «, Journal for the Education of the Gifted, 37(1), pp. 94-103.

/26// Rahwan, I., Ramchurn, S. D., Jennings, N. R., Mcburney, P., Parsons, S., \& Sonenberg, L. (2003), "Argumentation-based negotiation«, The Knowledge Engineering Review, 18(4), pp. 343-375.

/27/ Sadler, T. D. (2006). »Promoting discourse and argumentation in science teacher education «, Journal of Science Teacher Education, 17(4), pp. 323346.

/28/ Gollob, R., Huddleston E., Krapf, P., Salema, M. H., Spajić-Vrkaš, V. (2007), Education for democratic citizenship 2001-2004 "Tool on Teacher Training for Education for Democratic Citizenship and $\mathrm{Hu}$ man Rights Education". DGIV/EDU/CIT (2004) 44rev5 Rev (Sept 2007), Strasbourg: Council of Europe. 